\title{
VERTICAL TRANSMISSION OF HEPATITIS C VIRUS IN A HOSPITAL IN SOUTHERN BRAZIL
}

\author{
Mário Ferreira PEIXOTO ${ }^{1}$, Angelo Alves de MATTOS $^{2}$ \\ José Oscar dos Reis REMIÃO ${ }^{2}$, Cláudio Osmar Pereira ALEXANDRE², \\ Sibele Krebs de LEMOS$^{2}$ and Ana Maria Ponzio de AZEVEDO
}

Abstract - Background - There still are controversies concerning the vertical transmission of hepatitis C virus. Aim - To evaluate the prevalence of antibodies against hepatitis $\mathrm{C}$ virus in pregnant women, as well as the rate of vertical transmission of this virus. Patients and methods - Between August 1998 and November 1999, 1,090 consecutive pregnant women were screened for anti-hepatitis C virus; positive results were confirmed by the polymerase chain reaction assay. Patient's viral load was evaluated by the branched deoxyribonucleic acid assay. Hepatitis $C$ virus genotype was identified by direct sequencing of the polymerase chain reaction amplification products. The same tests were performed in the children born from infected mothers at the $1^{\text {st }}$ and $6^{\text {th }}$ month of life. Results - Of the 1,090 mothers surveyed, 29 were positive for anti-hepatitis C virus (prevalence of $2.66 \%$ ). Twenty-five patients presented with hepatitis C virus RNA, with a median hepatitis C virus viral load of $3.132 \pm 5.891 \mathrm{MEq} / \mathrm{mL}$. Twenty-two patients (six human immunodeficiency virus-coinfected) were followed and gave birth to 23 children; 18 of them had blood samples tested at the $1^{\text {st }}$ month of life, and 22 , at the $6^{\text {th }}$ month. Vertical transmission rate was $5.56 \%$; it affected a girl who had hepatitis C virus RNA detectable only in the $1^{\text {st }}$ month sample $(41.570 \mathrm{MEq} / \mathrm{mL})$. The mother who transmitted hepatitis $\mathrm{C}$ virus was coinfected with human immunodeficiency virus and presented with an hepatitis $\mathrm{C}$ virus viral load of $3.765 \mathrm{MEq} / \mathrm{mL}$, with $100 \%$ homology with her daughter's hepatitis C virus genotype. Conclusion - These results suggest that the prevalence of hepatitis $\mathrm{C}$ virus infection in pregnant women should not be neglected, and early diagnosis of vertical transmission and the follow up of infected children should be emphasized.

HEADINGS - Hepatitis C, transmission. Disease transmission, vertical. HIV. Pregnancy complications, infectious.

\section{INTRODUCTION}

The worldwide prevalence of antibodies against hepatitis $\mathrm{C}$ virus (anti-HCV) in blood donors has been shown to range from $0.2 \%$ to $2.7 \%{ }^{(2,3)}$. On the other hand, the prevalence of anti-HCV varies from $1.0 \%$ to $3.0 \%$ in general population ${ }^{(1,3)}$ and from 0 to $13 \%$ in pregnant women $(5,16,17,20,22,24,25,26,29,30,33,36)$.

In pregnant women, the diagnosis of hepatitis $\mathrm{C}$ virus (HCV) infection is particularly important to evaluate vertical transmission. The rate of neonatal transmission estimated in review articles varies from $4.5 \%$ to $6.0 \%(7,8,21,31,38)$. Even though while some authors were not able to find vertical transmission ${ }^{(10,30)}$, others found a transmission rate varying from $2.3 \%$ to $33 \%(4,5,6,11,12$, $15,16,17,18,20,22,23,24,25,26,27,28,32,33,34,36,37,39)$.

Some authors found out that transmission could be increased in the presence of human immunodeficiency virus (HIV) coinfection $^{(18,27,28,35,36,37)}$, while other authors did not ${ }^{(4,5,9,16,19,39)}$. Another factor that may be associated with increased transmission is the maternal viral load $(4,11,14,22,24,26,34,35)$, although there is no consensus on this subject ${ }^{(4,12,16,20,28,29,36,37)}$. HCV genotype has also been investigated as a cause of increased transmission ${ }^{(18,34}$, ${ }^{35,36,39)}$, but only one study ${ }^{(39)}$ suggests this influence.

In Brazil, no studies concerning vertical transmission of HCV have been carried out. Thus, the objective of the present study is to assess the prevalence of anti-HCV in pregnant women and to determine the rate of vertical transmission.

\section{PATIENTS AND METHODS}

From August 1998 to November 1999, 1,090 consecutive pregnant women followed at the Prenatal Care Clinic at "Hospital Nossa Senhora da Conceição" were screened for anti-HCV. Those with a positive test result were invited to join the study.

A blood sample was collected, and the serum was separated into two aliquots: one was stored at $-80^{\circ} \mathrm{C}$ for further determination of hepatitis $\mathrm{C}$ virus ribonucleic acid (HCV RNA) presence, viral

\footnotetext{
${ }^{1}$ Department of Infectious Diseases, "Hospital Nossa Senhora da Conceição", ${ }^{2}$ Department of Internal Medicine, "Fundação Faculdade Federal de Ciências Médicas de Porto Alegre"; Porto Alegre, RS, Brazil.

Address for correspondence: Dr. Angelo Alves de Mattos - Curso de Pós-Graduação em Hepatologia - Fundação Faculdade Federal de Ciências Médicas de Porto Alegre - Rua Cel. Aurélio Bitencourt, 35/201 - 90430-080 - Porto Alegre, RS, Brazil. E-mail: hmb@santacasa.tche.br
} 
load, and genotyping, and the other was used to investigate the levels of alanine aminotransferase (ALT) and aspartate aminotransferase (AST), as well as the presence of antibodies against hepatitis B virus surface antigen (anti-HBs) and core antigen (anti-HBc). The screening for hepatitis B virus surface antigen ( $\mathrm{HBsAg}$ ) and antibody against HIV (anti-HIV) had been previously carried out as part of the hospital's prenatal care routine.

Mothers were considered HCV-infected when they were positive for anti-HCV and HCV RNA by polymerase chain reaction (PCR).

Patients who presented with a positive test for HCV RNA were followed during pregnancy. After delivery, one blood sample was collected from the newborn children within the $1^{\text {st }}$ month of life, and a second one in the $6^{\text {th }}$ month. Each sample was separated into two aliquots: one was stored at $-80^{\circ} \mathrm{C}$ for further HCV RNA identification, quantification, and genotyping, and the other was used to investigate the presence of anti-HCV and the levels of ALT and AST. The children were investigated for the presence of anti-HIV and for hepatitis B virus infection when their mothers were coinfected.

The levels of AST and ALT were determined by commercial methods (AST FLEX $^{\mathrm{TM}}$ and ALT FLEX ${ }^{\mathrm{TM}}$, AR model of the DIMENSION ${ }^{\mathrm{TM}}$ system, Dade Behring Inc., Newark, DE, USA). Anti-HIV was detected by the microparticle enzyme immunoassay (MEIA) (AxSYM ${ }^{\mathrm{TM}} \mathrm{HIV}-1 / \mathrm{HIV}-$ 2, Abbott Diagnostics Division, Illinois, USA) and by the immune chromatographic assay Determine ${ }^{\mathrm{TM}} \mathrm{HIV}-1 / 2$ (Abbott Diagnostics Division, Illinois, USA). Positive samples were submitted to confirmation testing by a cultured cell layer immunofluorescence test ("Fundação Oswaldo Cruz", Rio de Janeiro, RJ, Brazil). Anti-HCV was detected by MEIA AxSYM ${ }^{\mathrm{TM}} \mathrm{HCV} 3.0$ (Abbott Diagnostics Division, Illinois, USA). HCV RNA was detected by PCR (HCV AMPLICOR ${ }^{\mathrm{TM}}$, Roche Diagnostics Systems, Inc., Branchburg, NJ, USA) and quantified by the branched desoxyribonucleic acid signal amplification test (b-DNA) (Quantiplex ${ }^{\mathrm{TM}}$ HCV RNA 2.0, Chiron Diagnostics, California, USA). The HCV genotyping was done by a direct sequencing method of the PCR AMPLICOR ${ }^{\mathrm{TM}}$ amplification products.

This study was approved by the hospital's ethics committee. In addition, all the patients included in the study gave their written informed consent.

In the statistical analysis, average was used for demographic data and median was used for HCV viral load values because of the variation that was found.

The comparison between HCV/HIV-coinfected and non-coinfected patients was analysed by Kruskal-Wallis's test, with a significance level of $5 \%$.

\section{RESULTS}

Of 1,090 pregnant women surveyed, 29 were anti-HCV-positive, which means a prevalence of $2.66 \%$. The anti-HCV test was carried out at $24.08 \pm 8.95$ weeks of pregnancy. To study vertical transmission, 25 patients who had a positive PCR result for HCV were assessed ( 8 with HIV coinfection). The age average was $27.6 \pm 7.07$ years (17 to 42 years); $56 \%$ were Caucasian. No patient had hepatitis B positive serology or signs or symptoms of liver disease.

Median maternal HCV viral load was $3.132 \pm 5.891 \mathrm{MEq} / \mathrm{mL}$ (mean $=5.139 \pm 5.891 \mathrm{MEq} / \mathrm{mL}$ ), ranging from $<0.200 \mathrm{MEq} / \mathrm{mL}$ to 21.420 $\mathrm{MEq} / \mathrm{mL}$. In those HIV-coinfected mothers, median HCV viral load was $5.191 \pm 4.476 \mathrm{MEq} / \mathrm{mL}($ mean $=6.158 \pm 4.476 \mathrm{MEq} / \mathrm{mL})$ while in non-coinfected mothers, median was $2.459 \pm 6.521 \mathrm{MEq} / \mathrm{mL}$ (mean $=4.659 \pm 6.521 \mathrm{MEq} / \mathrm{mL})$. These results did not present statistical difference $(P=0.116)$.

The most prevalent maternal genotypes were $3 \mathrm{a}$ (eight patients), $1 \mathrm{~b}$ (seven patients) and $1 \mathrm{a}$ (six patients). Genotype $2 \mathrm{~b}$ was observed in two patients, and genotype $3 \mathrm{c}$, in one patient. One sample was not suitable for sequencing.

Three patients were excluded from the study: one of them had a miscarriage and two (HIV-coinfected) were lost during the follow-up period. The 22 patients who remained in the study (6 HIV-positive) were followed and gave birth to 23 children (one set of twins), 13 females and 10 males. Patients with HIV coinfection had a median CD4 count of $485.5 \pm 267.2$ cells $/ \mathrm{mm}^{3}$ (varying from 307 to 1,030 cells $/ \mathrm{mm}^{3}$ ). Deliveries occurred at an average of $38.26 \pm 2.94$ weeks of pregnancy ( 30 to 42 weeks). There were 12 cesarean sections and 10 vaginal deliveries. Six children had an Apgar score below 8 at the $1^{\text {st }}$ minute, but all 23 children presented an Apgar score above 8 at the $5^{\text {th }}$ minute.

Blood samples were collected from 18 of the 23 children in the $1^{\text {st }}$ month of life; all were positive for anti-HCV. Twenty-two children had their blood tested at the $6^{\text {th }}$ month of life; anti-HCV was detected in seven cases $(31.82 \%)$. Taking into consideration the 17 children who had two blood samples tested (at the $1^{\text {st }}$ and $6^{\text {th }}$ months of life), anti$\mathrm{HCV}$ became negative in $58.82 \%$ at the age of 6 months.

Only one child, a girl born after vaginal delivery, presented positive PCR results at the $1^{\text {st }}$ month of life, with a viral load of $41.570 \mathrm{MEq} / \mathrm{mL}$ and genotype 3a. That means a vertical transmission rate of $5.56 \%$ $(1 / 18)$. By the age of 6 months, the blood of this child was tested again: anti-HCV was still present, but HCV RNA could not be detected by PCR. The AST levels of this child were normal in the $1^{\text {st }}$ month $(20 \mathrm{U} / \mathrm{L})$ and elevated in the $6^{\text {th }}$ month of life $(55 \mathrm{U} / \mathrm{L})$, when PCR did not detect HCV RNA anymore, being normal again in a future determination $\left(12^{\text {th }}\right.$ month); ALT was always normal. Her mother was HIV-coinfected, with an $\mathrm{HCV}$ viral load of $3.765 \mathrm{MEq} / \mathrm{mL}$ and genotype 3a (the genotype homology with the child's virus was $100 \%$ ). All other children submitted to PCR tested negative at both ages.

\section{DISCUSSION}

The prevalence of anti-HCV in pregnant women $(2.66 \%)$ was higher than the prevalence found $(1.74 \%)$ for blood donors in the same hospital ${ }^{(2)}$. This was expected, since blood donors are a select group, not representative of the general population ${ }^{(3)}$. It was also higher than the percentages reported in most studies with pregnant women worldwide, which ranges from $0 \%$ to $1.2 \%{ }^{(1,4,20,22,24,25,26,30,33)}$, even though some investigators $^{(5,17,29)}$ have reported similar prevalences $(1.7 \%$ to $2.6 \%)$.

It is important to realize that we did not observe significant differences in the HCV viremia detected in HIV-coinfected mothers and in non-coinfected ones, as corroborated by other authors ${ }^{(5,19)}$. On the other hand, there are different opinions ${ }^{(36,37)}$, suggesting that a lower immunity induced by HIV allows a greater HCV viral load to exist. Even though, it is to be emphasized, that the HIV-coinfected patients evaluated in this study had a good immunologic status (median CD4 count of 485 cells $/ \mathrm{mm}^{3}$ ).

It is widely accepted ${ }^{(4,5,10,13,17,20,27,32,33,34,36,39)}$ that, in most of the children, anti-HCV passive antibodies will disappear in the first 12 months of life. We detected anti-HCV in all children tested at the $1^{\text {st }}$ month. However, by the $6^{\text {th }}$ month, $58.82 \%$ had negativated the anti-HCV, as expected. 
A limited number of studies on vertical transmission of $\mathrm{HCV}$ showed a clear distinction between individuals with or without detectable HCV $\mathrm{RNA}^{(20,24,32,33,39)}$. Most of the studies were based only on the anti-HCV status of the patients, which may result in questionable rates. In the present study, only pregnant women who were HCV-positive by PCR were included ${ }^{(17,23,26,34)}$. This way, we found a vertical transmission rate of $5.56 \%$ in which the presence of HCV RNA in the children's blood samples was taken into consideration. This corresponds to the $4.5 \%$ to $6 \%$ rate reported in literature reviews ${ }^{(7,8,21,31,38)}$, as well as in other original papers ${ }^{(5,25,37)}$.

We should also consider the diagnosis criteria for this infection in children, since some authors considered a child as HCV-infected

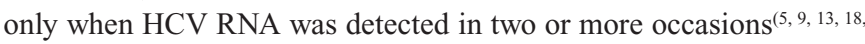
${ }^{28)}$, while others accepted as a criterion for vertical transmission the occurrence of at least one positive PCR sample at any time ${ }^{(4,6,11,22,30 \text {, }}$ 36). Since most of the studies do not follow the children for a long time after birth, SPENCER et al. ${ }^{(34)}$ suggest that this should be done in order to observe whether the viral clearance is transitory or permanent. In our study, the sample of the infected child was positive at the $1^{\text {st }}$ month of life, and clearance occurred by the age of 6 months; this could be considered as a transient viremia by some authors ${ }^{(5,28)}$.

For several authors ${ }^{(4,11,14,22,24,26,35,36)}$, the viremia level of an $\mathrm{HCV}$-positive mother is related to vertical transmission. However, other investigators do not agree ${ }^{(5,13,17,20,28,29,36,37)}$. Literature data are not consistent regarding HCV viral load determined by the bDNA technique as a risk factor for vertical transmission. OKAMOTO et al. ${ }^{(26)}$ found higher viral load values among mothers who transmitted the infection to their children than among those who did not. MORIYA et al. ${ }^{(22)}$ diagnosed vertical transmission only when the mother's viral load was higher than $5.0 \mathrm{MEq} / \mathrm{mL}$. However, ZANETTI et al. ${ }^{(36)}$, when comparing mothers who transmitted HCV and those who did not, found out that the HCV viral load was not different between the two groups. This result was corroborated by a more recent study carried out by the same group ${ }^{(37)}$. Also, other studies did not find out any difference concerning the viral load ${ }^{(13,28)}$. On the other hand, for PIPAN et al. ${ }^{(29)}$, vertical transmission was absent even when HCV RNA blood levels were above $1.0 \mathrm{MEq} / \mathrm{mL}$.

In the case of vertical transmission observed in our study, the mother was HIV-coinfected and had a HCV viral load of $3.765 \mathrm{MEq} / \mathrm{mL}$, which was not much higher than the $3.132 \mathrm{MEq} / \mathrm{mL}$ median value found for the whole group, though lower than the $5.191 \mathrm{MEq} / \mathrm{mL}$ median value observed for the HIV-coinfected mothers. Due to the fact that in our study only one case of vertical transmission was found, it is hard to draw any conclusion regarding the influence of maternal $\mathrm{HCV}$ viral load and HIV coinfection on vertical transmission of HCV.

Our case of vertical transmission occurred with an HIV-coinfected mother, which constitutes a situation considered to be relevant for the vertical transmission of $\mathrm{HCV}^{(18,27,28,35,36,37)}$.

Most of the studies investigating the correlation between $\mathrm{HCV}$ genotype and vertical transmission were not able to establish a clear association between both ${ }^{(18,34,35,36,37)}$. ZUCCOTTI et al. ${ }^{(39)}$, on the other hand, considered genotypes $1 \mathrm{~b}$ and $3 \mathrm{a}$ more frequent in cases of vertical transmission, although they were also more prevalent in HIVcoinfected mothers; this could be seen as a bias in the experiment. Our study showed that vertical transmission occurred in an HIV-coinfected mother with genotype $3 \mathrm{a}$, with $100 \%$ of homology with that observed in her daughter; this could be taken as an indication of mother-to-child transmission route.

To summarize, though vertical transmission of HCV seems to be infrequent, except perhaps for HIV-coinfected mothers, we conclude that the prevalence of HCV infection in pregnant women should not be neglected. Thus, anti-HCV screening should be indicated in the prenatal care routine of pregnant women with risk behavior for $\mathrm{HCV}$ infection, mainly in the cases of those coinfected by HIV. Since we still do not have therapeutic measures or obstetric procedures to reduce the risk of vertical transmission of $\mathrm{HCV}$, early diagnosis and follow-up of the infected children should be emphasized.

Peixoto MF, Mattos AA, Remião JOR, Alexandre COP, Lemos SK, Azevedo AMP. Transmissão vertical do vírus da hepatite C em um hospital do sul do Brasil. Arq Gastroenterol 2004;41(2):84-7.

RESUMO - Racional - Ainda existem controvérsias em relação à transmissão vertical do vírus da hepatite C (VHC). Objetivo - Avaliar a prevalência dos anticorpos contra o VHC (anti-VHC) em mulheres grávidas, bem como a percentagem de transmissão vertical observada. Pacientes e Métodos - Entre agosto de 1998 e novembro de 1999, 1.090 mulheres grávidas consecutivas realizaram a determinação do anti-VHC. A confirmação do teste foi feita pela reação em cadeia da polimerase. A carga viral foi determinada pelo b-DNA e o genótipo por seqüenciamento. Os mesmos testes foram realizados no 1ำ e 6o mês de vida, nas crianças nascidas de mães infectadas. Resultados - Das 1.090 mães estudadas, 29 apresentaram positividade para o anti-VHC (prevalência de 2,66\%). Em 25 pacientes foi demonstrado o RNA do VHC, sendo que a carga viral média foi de 3,132 $\pm 5,891 \mathrm{MEq} / \mathrm{mL}$. Vinte e duas pacientes $(6$ co-infectadas com o vírus da imunodeficiência humana) foram seguidas e deram à luz a 23 crianças, das quais 18 tiveram seu sangue testado no $1^{\circ}$ mês e 22 no $6^{\circ}$ mês. Foi observada transmissão vertical em 5,56\% dos casos. Assim, em uma criança do sexo feminino foi detectado o RNA do VHC (41,570 MEq/mL). A mãe desta criança estava co-infectada pelo vírus da imunodeficiência humana e apresentava carga viral de $3,765 \mathrm{MEq} / \mathrm{mL}$, com $100 \%$ de homologia no genótipo viral. Conclusão - Estes resultados sugerem que a prevalência da infecção pelo VHC em gestantes não deve ser negligenciada e que um diagnóstico precoce e o seguimento das crianças infectadas deve ser preconizado.

DESCRITORES - Hepatite C, transmissão. Transmissão vertical de doença. HIV. Complicações infecciosas na gravidez. 


\section{REFERENCES}

1. Alberti A, Chemello L, Benvegnù L. Natural history of hepatitis C. J Hepatol 1999;31:17-24

2. Almeida PRL, Mattos AA, Ulbrich-Kutczynski J, Czerski CT, Geyer G. Prevalência e impacto histológico da infecção pelo vírus $\mathrm{C}$ em doadores de sangue. GED Gastroentero Endosc Dis 1998;17:121-8.

3. Alter MJ. The epidemiology of acute and chronic hepatitis C. Clin Liver Dis 1997;1:559-68

4. Casanovas Lax J, Silva García G, Vargas Romero J, Nogales Pérez MC, Aguayo Maldonado J, Cruz Guerrero G, González Hachero J. Transmisión vertical del vírus de la hepatitis C. An Esp Pediatr 1997;47:627-32.

5. Conte D, Franquelli M, Prati D, Colucci A, Minola E. Prevalence and clinical course of chronic hepatitis $\mathrm{C}$ virus (HCV) infection and rate of $\mathrm{HCV}$ vertical transmission in a cohort of 15,250 pregnant women. Hepatology 2000;31:751-5.

6. Croxson M, Couper A, Voss L, Groves D, Gunn T. Vertical transmission of hepatitis C virus in New Zealand. N Zealand Med J 1997;110:165-7.

7. Dienstag J. Sexual and perinatal transmission of hepatitis C. Hepatology 1997;26 Suppl:66-70

8. Eriksen NL. Perinatal consequences of hepatitis C. Clin Obstet Gynecol 1999;42:121-33

9. Fioredda F, Ranicri E, Lorusso C, Loy A, Antinozzi A, Rocca P, Gotta C, Bassetti D Vertical transmission of hepatitis C [letter]. Pediatr Infect Dis J 1996;15:642.

10. Fischler B, Lindh G, Lindgren S, Forsgren M, Von Sydow M, Sangfelt P, Alaeus A, Harland L, Enockson E, Nemeth A. Vertical transmission of hepatitis C virus infection. Scand J Infect Dis 1996;28:353-6.

11. Garland SM, Tabrizi S, Robinson P, Hughes C, Markman L, Devenish W, Kliman L. Hepatitis C - role of perinatal transmission. Austr New Zeal J Obstet Gynaecol 1998;38:424-7.

12. Gibb DM, Goodall RL, Dunn DT, Healy M, Neave P, Cafferkey M, Butler K. Motherto-child transmission of hepatitis $\mathrm{C}$ virus: evidence for preventable peripartum transmission. Lancet 2000;356:904-7.

13. Granovsky MO, Minkoff HL, Tess BH, Waters D, Hatzakis A, Devoid DE, Landesman SH, Rubinstein A, Bisceglie AM, Goedert JJ. Hepatitis C virus infection in the mothers and infants cohort study. Pediatrics 1998;102:355-9.

14. Hunt CM, Carson KL, Sharara AI. Hepatitis C in pregnancy. Obstet Gynecol 1997;89:883-90

15. Ketzinel-Gilad M, Colodner SL, Hadary R, Granot E, Shouval D, Galun E. Transient transmission of hepatitis $\mathrm{C}$ virus from mothers to newborns. Eur J Clin Microbiol Infect Dis 2000;19:267-74.

16. Kumar RM, Frossad PM, Hughes PF. Seroprevalence and mother-to-infant transmission of hepatitis C in asymptomatic Egyptian women. Eur J Obstet Gynecol Reprod Biol 1997;75:177-82

17. La Torre A, Biadaioli R, Capobianco T, Colao MG, Monti M, Pulli F, Visioli CB, Zignego AL, Rubaltelli F. Vertical transmission of HCV. Acta Obstet Gynecol Scand 1998;77:889-92

18. Maccabruni A, Bossi G, Caselli D, Cividini A, Silini E, Mondelli MU. High efficiency of vertical transmission of hepatitis $\mathrm{C}$ virus among babies born to human immunodeficiency virus-negative women. Pediatr Infect Dis J 1995;14:921-2.

19. Manzini P, Saracco G, Cherchier A, Riva C, Musso A, Ricotti E, Palomba E, Scolfaro C, Verme G, Bonino F, Tovo PA. Human immunodeficiency virus infection as risk factor for mother-to-child hepatitis $\mathrm{C}$ virus transmission; persistence of anti-hepatitis $\mathrm{C}$ virus in children is associated with the mother's anti-hepatitis $\mathrm{C}$ virus immunoblotting pattern. Hepatology 1995;21:328-32.

20. Matsubara T, Sumazaki R, Takita H. Mother-to-infant transmission of hepatitis C virus: a prospective study. Eur J Pediatr 1995;154:973-8.

21. Michielsen PP, Van Damme P. Viral hepatitis and pregnancy. Acta Gastroenterol Belg 1999;62:21-9.

22. Moriya T, Sasaki M, Mizui M, Ohno N, Mohri H, Mishiro S, Yoshizawa H. Transmission of hepatitis $\mathrm{C}$ virus from mother to infants: its frequency and risk factors revisited. Biomed Pharmacother 1995;49:59-64.
23. Ni Y-H, Lin H-H, Chen P-J, Hsu H-Y, Chen D-S, Chang M-H. Temporal profile of hepatitis $\mathrm{C}$ virus antibody and genome in infants born to mothers infected with hepatitis $\mathrm{C}$ virus but without human immunodeficiency virus coinfection. J Hepatol 1994;20:641-5

24. Ohto H, Terazawa S, Sasaki N, Sazaki N, Hino K, Ishiwata C, Kako M, Ujiie N, Endo C, Matsui A, Okamoto H, Mishiro S. Transmission of hepatitis C virus from mothers to infants. The Vertical Transmission of Hepatitis C Virus Collaborative Study Group. N Engl J Med 1994;330:744-50.

25. Okamoto M, Nagata I, Murakami J, Hino S, Shiraki K. Shift in the buoyant density of hepatitis $\mathrm{C}$ virus particles in infants infected by mother-to-infant transmission. Pediatr Int 1999;41:369-73.

26. Okamoto M, Nagata I, Murakami J, Kaji S, Iitsuka T, Hoshika T, Matsuda R, Tazawa Y, Shiraki K, Hino S. Prospective reevaluation of risk factors in mother-to-child transmission of hepatitis $\mathrm{C}$ virus: high virus load, vaginal delivery, and negative antiNS4 antibody. J Infect Dis 2000;182:1511-4.

27. Paccagnini S, Principi N, Massironi E, Tanzi E, Romanò L, Muggiasca ML, Ragni MC, Salvaggio L. Perinatal transmission and manifestation of hepatitis C virus infection in high risk population. Pediatr Infect Dis J 1995;14:195-9.

28. Papaevangelou V, Pollack H, Rochford G, Kokka R, Hou Z, Chernoff D, Hanna B, Krasinski K, Borkowsky W. Increased transmission of vertical hepatitis C virus (HCV) infection to human immunodeficiency virus (HIV)-infected infants of HIV- and HCVcoinfected. J Infect Dis 1998;178:1047-52.

29. Pipan C, Amici S, Astori G, Ceci GP, Botta GA. Vertical transmission of hepatitis C virus in low-risk pregnant women. Eur J Clin Microbiol Infect Dis 1996;15:11620.

30. Quero MSB, Suarez MG, Muñoz GG, Torres MS, Peña MC. Prevalencia de anticuerpos anti virus hepatitis C (HCV) en una población de embarazadas de Santiago. Rev Med Chile 1995;123:907-8

31. Reinus JF, Leikin EL. Viral hepatitis in pregnancy. Clin Liver Dis 1999;3:115-25.

32. Resti M, Azzari C, Lega L, Rossi ME, Zammarchi E, Novembre E, Vierucci A. Mother-to-infant transmission of hepatitis C virus. Acta Paediatr 1995;84:251-5.

33. Sabatino G, Ramenghi LA, di Marzio M, Pizzigallo E. Vertical transmission of hepatitis C virus: an epidemiological study on 2,980 pregnant women in Italy. Eur J Epidemiol 1996;12:443-7.

34. Spencer JD, Latt N, Beeby PJ, Collins E, Saunders JB, McCaughan GW, Cossart YE. Transmission of hepatitis $\mathrm{C}$ virus to infants of human immunodeficiency virus-negative intravenous drug-using mothers: rate of infection and assessment of risk factors for transmission. J Viral Hepat 1997;4:395-409.

35. Thomas DL, Villano SA, Riester KA, Hershow R, Mofeson LM, Landesman SH, Hollinger FB, Davenny K, Riley L, Diaz C, Tang HB, Quinn TC. Perinatal transmission of hepatitis $\mathrm{C}$ virus from human immunodeficiency virus type 1-infected mothers. J Infect Dis 1998;177:1480-8.

36. Zanetti AR, Tanzi E, Paccagnini S, Principi N, Pizzicolo G, Caccamo ML, D’Amico E, Cambiè G Vecchi L, and The Lombardy Study Group on Vertical HCV Transmission. Mother-to-infant transmission of hepatitis C virus. Lancet 1995;345:289-91.

37. ZanettiAR, Tanzi E, Romanò L, Zuin G, Minola E, Vecchi L, Principi N. A prospective study on mother-to-infant transmission of hepatitis C virus. Intervirology 1998;41:208-12.

38. Zanetti AR, Tanzi E, Newell ML. Mother-to-infant transmission of hepatitis C virus. J Hepatol 1999;31 Suppl:96-100

39. Zuccotti GV, Ribero ML, Giovannini M, Fasola M, Riva E, Portera G, Biasucci G, Decarlis S, Profeta ML, Tagger A. Effect of hepatitis C genotype on mother-to-infant transmission of virus. J Pediatr 1995;127:278-80. 